

\title{
Assessment of Groundwater Recharge Potential Depending on Morphologic Analysis in East of Wasit, Southeastern Iraq
}

\author{
Mohammed S. Shamkhi ${ }^{1}$ and Hassan Jameel Al-Badry ${ }^{1, *}$ \\ 1 Department of Civil Engineering, College of Engineering, Wasit University; Iraq \\ * Correspondence: hjalbadry@ gmail.com
}

Received: 27 April 2021; Accepted: 16 July 2021; Published: 31 October 2021

\begin{abstract}
Modern technologies are used for watershed management to cope with drought risks in arid and semi-arid regions. The study aimed to conduct a morphometric analysis and know potential groundwater recharge areas in the eastern region of Wasit Province. Remote sensing and GIS data were used for morphometric analysis. The morphometric analysis results adopted the Digital Elevation Model. The results of the analysis were verified by matching the results with what exists in reality. The area of the first basin was 1482.017 , as it is the largest basin from the area, with a percent of $51.228 \%$ of the total area of all basins. The percentage of first-degree flows reached $83.37 \%$ in the first basin, $74.14 \%$ percent in the second basin, $75.51 \%$ in the third basin, and $75.75 \%$ in the fourth basin from all streams in each basin. The bifurcation rate (3.135-4.233), Stream frequency range values (0.543-0.332), drainage texture coarse, low drainage density that ranged between $0.986-1.14 \mathrm{~km} / \mathrm{km} 2$ elongation ratio ranging from 0.348-0.624 form factor (0.095-0.316). The basins' circularity $(0.105-0.238)$ relief value $(951-112) \mathrm{m}$ infiltration number value (0.369-0.535). All basins have a longitudinal shape and lead to the formation of floods and rapid currents, which exposes the region to rapid seasonal floods and the creation of flash floods that cause soil erosion and analyses the drainage intensity results. It was low, and this is an indication that the ground has high permeability. The flow frequency results indicate that the area is semi-arid and exposed to small amounts of rain and coarse drainage texture by comparing the result parameters from morphometric analysis results for each basin. The potential recharge areas of groundwater in the study area can be known, $\mathrm{n}$ as the analysis results showed that recharge potential occurs in all basins. The highest groundwater recharge is possible in the third basin and the lowest in the first basin. Morphometric analysis was performed by ARC-GIS(Arc-map10.4).
\end{abstract}

Keywords: Groundwater recharge; Morphometric analysis; East Wasit; Iraq; ArcGIS

\section{Introduction}

The population increase due to population growth led to an increase in industrial expansion and an increase in land use in the region, and as a result, an increase in groundwater withdrawals in conjunction with a decrease in rainfall rates where climate forecasts that indicate that the Middle East region in general and Iraq, in particular, will witness a decrease in the rates of rainfall (Awad and Ahmad 2012; Al-Ansari, 2013). Moreover, this, in turn, affects the recharge of groundwater and its low levels and the discharge of the Tigris and Euphrates rivers, and in general, the water surface, which will become more susceptible to pollution due to lower levels and increased concentrations of pollutants. Therefore, attention and focus must be placed on the sources of groundwater recharge. The watersheds must be

DOI: 10.46717 igj.54.2D.11Ms-2021-10-30 
developed. Critical in the recharge process. It is necessary to determine groundwater recharge sites, as the variation in the area's topography is an essential factor in determining these sites. The hydrological characteristics of soil also play a vital role in groundwater storage, movement and recharge, as these characteristics constitute a physical system for water basins) Kulkarni, 1998; Al-Hamdani et al., 2016a; Al-Hamdani et al., 2016b). The musted understand the governing parameters, hydrological, hydrogeological, geomorphology and geology; properly manage the available water resources, whether it is surface or groundwater, it is essential to understand the hydrological characteristics of a watershed. This is done by conducting the morphometric analysis and knowing the water basins (Dwivedi, 2011). The morphometric analysis also provides an understanding of the process of feeding rain and knowing the potential of groundwater (Magesh and Chandrasekar, 2014). The rain and percolate water are the primary groundwater source that reaches the aquifer through the soil pores. As a result of the technological development of remote sensing and spatial analysis techniques that use the GIS program in the management of water resources and hydrological analysis, morphometric analysis applying remote sensing and geographic data systems (GIS) has become an accurate and highly efficient method in designing groundwater potentials and the drainage system for any area. The analysis describes the shape of the water basins and the basins' surface characteristics and provides information about the area's topography. By measuring the various hydrological parameters, we obtain necessary information regarding the water basin's groundwater potential (Dwivedi, 2011; Mallick et al., 2019; Ostad-AliAskari et al., 2019). Many researchers studied water basins, where the morphometric analysis was performed using remote sensing and geographic information systems (GIS) techniques. Morphometric analysis was used to study the basin's physical properties to find the effect of runoff on soil erosion sediment accumulation in the water basin) Singh, 2020; Shamkhi et al., 2019a). Prediction of flood risk and its relationship to watershed physical properties (Shamkhi et al., 2020; Makhamreh et al., 2020). Watershed physical properties and their relationship to water basin runoff (Shamkhi et al., 2019b). By combining a remote sensing approach with a geographic information system, it is possible to know the geographic and geomorphological characteristics of a drainage basin and know the hydrological response to determine the possibility of groundwater (Verma et al., 2020; Ostad-Ali-Askari et al., 2020), etc. The morphometric parameters effectively determine the type of water drainage and smoothing out the basin area as the slopes, and high altitudes affect the drainage and the time the water stays inside the basin (Nasir et al., 2020; Kacem et al., 2014). Previous studies dealt with parts of the study area. (Shamkhi et al., 2019a) The drainage properties of a small portion of the area were derived (Shamkhi et al., 2020), Where some physical properties were studied and analyzed to reflect the characteristics of the rivers network area (Hilo and Saeed, 2019). To evaluate the quantity and quality of water income for a part of the study area and evaluate the best method (Manhi et al., 2021). Part of the study area was studied to estimate surface runoff in particular and assess the hydrological situation. The study aimed to conduct a morphometric analysis, understand drainage characteristics and know potential groundwater recharge areas in the eastern region of Wasit Province. It is considered the first study in which morphometric analysis is added to know the potential areas of groundwater and its recharge in the study area. Also, the current study is distinguished from previous studies in that it studies the shapes and characteristics of basins within the Iraqi borders, which gives a greater understanding of planners and engineers for sustainable management of water resources

\section{Study Area}

The study area is located in Iraq in Wasit, the eastern part, and it includes an area of about 5043 $\mathrm{km}^{2}$ and covers the two districts of Badrat, which includes the Jassan and Zurbatiyah and Sheikh Saad. The study area located between latitudes ( $32^{\circ} 30^{\prime}-33^{\circ} 30^{\prime}$ north) and longitude ( $45^{\circ} 30^{\prime}-46^{\circ} 45^{\prime}$ east), with the elevation of the area, ranging from 0-964.4 meters above sea level and decreases. The 
general slope of the land from the northeast to the southwest and from the eastern boundary towards the center (Fig.1). The terrain varies in the study area, where mountainous areas parallel to the borders separating Iraq from Iran and high altitudes are observed, followed by low valleys and places to collect water from mountain heights and highland areas. They are suitable and tributary places for the feeding process. The valleys' soils are often formed from the weathering of rocks in Mountie Highlands, where you will often find the valley's soil to be a rock girl in the surrounding high places. The study area vegetation cover consists mostly in the winter and spring seasons, which are times of rain when you notice the presence of herbaceous plants covering the area, and you notice that the convoys of livestock owners graze this area, in the summer, the weather is hot, arid areas, without vegetation, and dominated by drought, where there is no surface water. The only available is groundwater that can be used and harnessed the wealth of this region.

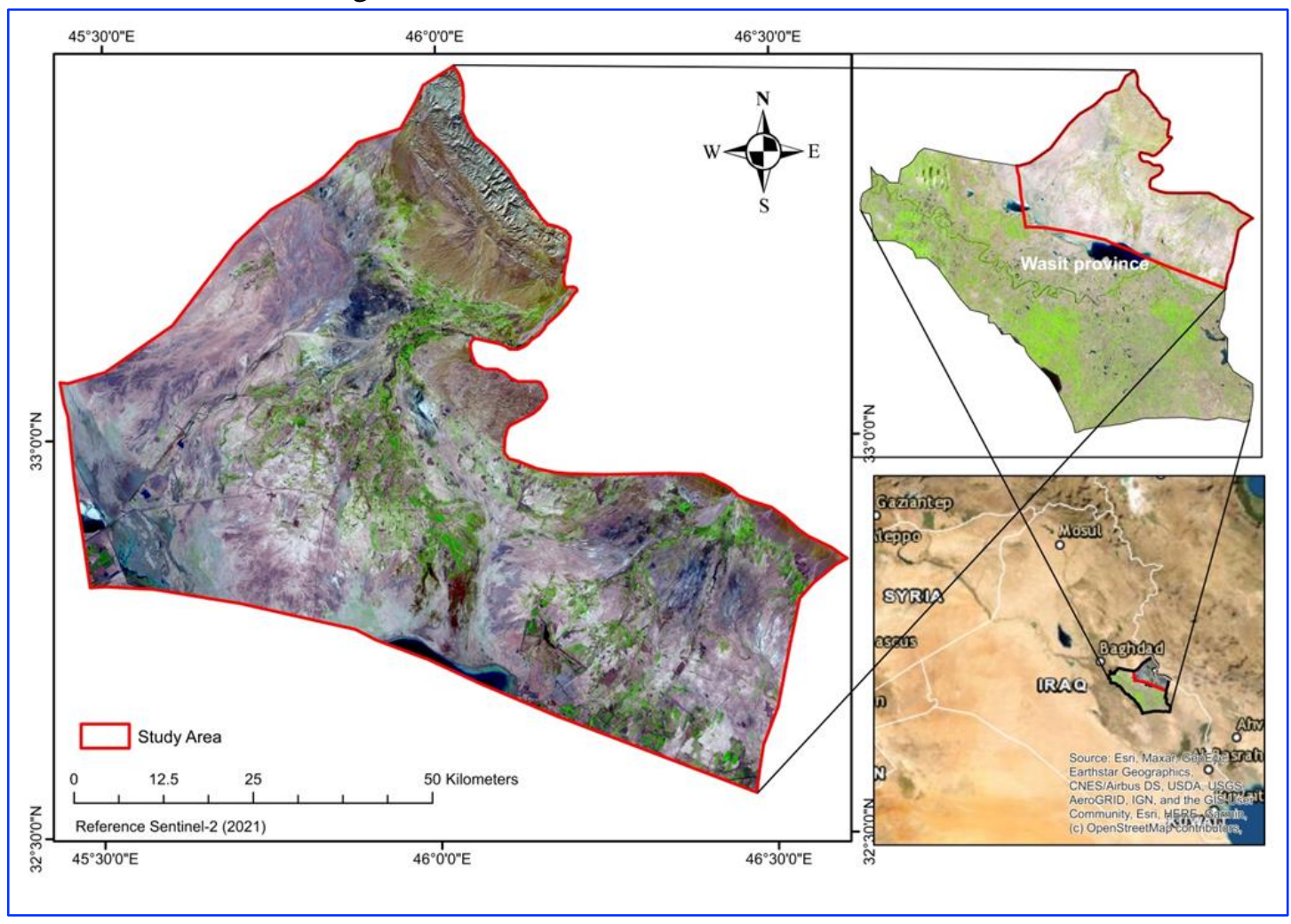

Fig. 1. Location map of the study area based on the image of the Sentinel-2(2021) satellite, using the ArcGIS program)

\section{Materials and Methods}

\subsection{Data Source}

The digital elevation model (DEM) (SRTM) with a resolution of 30 meters was downloaded from the US Geological Survey website. The number of images covering the study area was four images. First, these images were opened in Arc-Gis (Arc map) software. Next, the Extraction cut out the inside part of the image in the study area by mask tools included in the Arc Toolbox(Analysis tools) in the Arc map program, after opening the Shape file of the study area, after which a Mosaic To new Raster was made for all the images within the study area, where we obtained one image of the study area representing the digital height of the area (the topography for the area study), which ranged between 0 $964.4 \mathrm{~m}$ as shown in Fig. 2. 


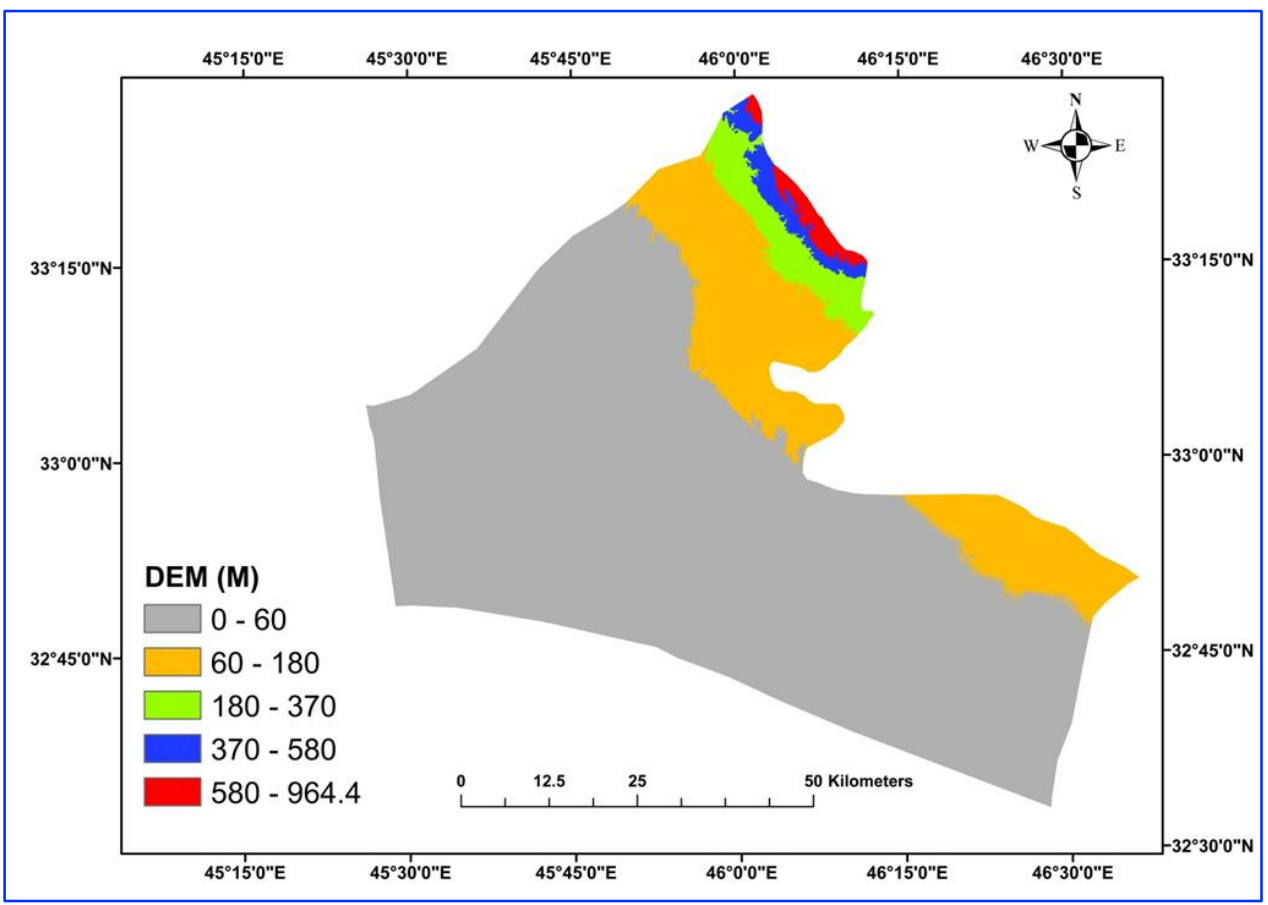

Fig.2. Digital elevation model of the study area (From the Author's work based on the DEM produced by SRTM and using ArcGIS s program)

\subsection{Hydrology Analysis}

The hydrological analysis is performed using Arc-map software, and from the toolbox window, the hydrological tools are used. It is found in the spatial analysis tools, as the hydrological tools include the toolkit that performs the hydrological analysis. The fill tool is used inside the spatial hydrological analysis tool to remove some extreme values. The flow direction is then determined using the flow direction tool, where the flow direction is used to determine the flow accumulation using the flow accumulation tool; next, determining the stream link, stream order raster, stream order vector, and define the water basins. Fig. 3 shows the hydrological analysis, the sequence of hydrological analysis processes, and the tools used.

\subsubsection{Fill tool}

This tool is used to remove some anomalies in the digital elevation model. This tool is located in the spatial analysis toolbox and hydrological analysis tools.

\subsubsection{Flow direction tool}

These tools are used to find out the direction of flow or drainage. Fill Dem input in this tool is used to extract the direction of flow.

\subsubsection{Flow accumulation}

This tool is used to know the places of water collection and uses the Flow direction in the previous step as an input to do so.

\subsubsection{Con tool}

This tool is selected from the spatial analysis toolbox, and then choose tools conditional. First, this tool is used to determine the value of the sensor. These tools use the flow Accumulation extracted in the 
previous step as an input; then we determine the value according to the area of the region and the density of water streams, where several values were used that gave a value of 1000 result more realistic and consistent with the reality in the study area and suitable for analyzing the area.

\subsubsection{Stream link}

this tool used to determine the streamline of the stream. This tool is within the tools of hydrological analysis. The first entrance to this tool is the result of the con tool, and the second entrance is the direction of flow.

\subsubsection{Stream order tool}

This tool is used to determine the streams ranks, where the first input streamline is the product of the previous step and the second input is the flow direction. We choose the Strahler method to determine the ranks of the stream.

\subsection{7. stream to feature tool}

The purpose of using this tool is to convert the stream order salary into the feature formula. The goal of this stage is to classify the river ranks later in the ArcGIS map program. This tool uses Stream Order as the first input and the flow direction as the second input.

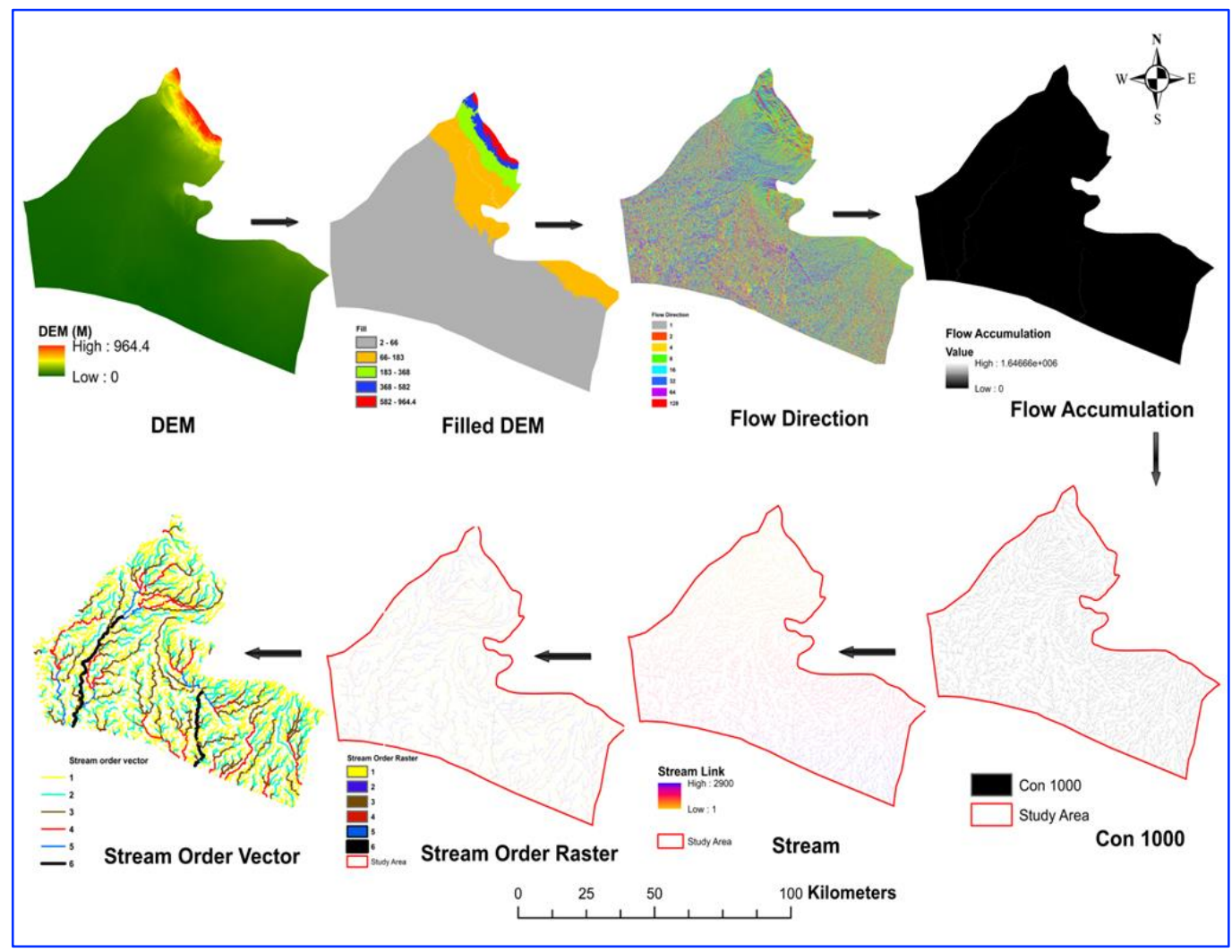

Fig. 3. Hydrology analysis ( based on the digital elevation model DEM produced by SRTM and using ArcGIS s program, hydrological analysis tools).

The morphometric analysis was done according to the formulas and equations are shown in Table 1, which shows the name of each parameter calculated, its mathematical formula, and the source. 
Table 1.The standard formula for computing different morphometric parameters

\begin{tabular}{|c|c|c|c|}
\hline No. & $\begin{array}{c}\text { Morphometric } \\
\text { parameters }\end{array}$ & Formulae Linear & References \\
\hline 1 & \multirow{2}{*}{$\begin{array}{c}\text { Stream order } \\
\text { Stream length }(\mathrm{Lu})\end{array}$} & \multirow{2}{*}{$\begin{array}{c}\text { Hierarchical rank } \\
\text { Length of the stream, km }\end{array}$} & (Strahler,164) \\
\hline 2 & & & (Horton, 1945) \\
\hline 3 & Mean stream length (Lsm) & $\mathrm{Lsm}=\mathrm{Lu} / \mathrm{Nu}$ & (Strahler,1964) \\
\hline 4 & Stream length ratio (RL) & $\begin{array}{c}\mathrm{Rl}=\mathrm{Lu} / \mathrm{L}(\mathrm{u}-1), \text { where } \mathrm{Lu} \text { is } \\
\text { stream length order } \mathrm{u} \text { and } \\
\mathrm{L}\left(\mathrm{u} \_1\right) \text { is stream segment } \\
\text { length of the subsequent } \\
\text { lower-order } \mathrm{Rb}\end{array}$ & (Horton, 1945) \\
\hline 5 & Bifurcation ratio $(\mathrm{Rb})$ & $\mathrm{Rb}=\mathrm{Nu} / \mathrm{Nu}+1$ & (Schumm, 1956) \\
\hline 6 & $\begin{array}{l}\text { Mean bifurcation ratio } \\
\qquad(\mathrm{Rbm})\end{array}$ & $\begin{array}{l}\mathrm{Rbm}=\text { average of } \\
\text { bifurcation ratios of all } \\
\text { stream order }\end{array}$ & (Strahler, 1964) \\
\hline 7 & $\begin{array}{l}\text { Length of overland flow } \\
\text { (Lg) }\end{array}$ & $\mathrm{Lg}=1 / \mathrm{Dx} 2, \mathrm{~km}$ & (Horton, 1945) \\
\hline 8 & Drainage density (Dd) & $\begin{array}{l}\mathrm{Dd}=\mathrm{Lu} / \mathrm{A}, \text { where } \mathrm{Lu} \text { is } \\
\text { total stream length, } \mathrm{A} \text { is an } \\
\text { area of the watershed }\end{array}$ & (Horton, 1945) \\
\hline 9 & Stream frequency $(\mathrm{Fs})$ & $\begin{array}{c}\mathrm{Fs}=\sum \mathrm{Nu} / \mathrm{Au} \text {, where } \mathrm{N} \text { is the } \\
\text { total number of streams, and } \\
\mathrm{A} \text { is the area of the } \\
\text { watershed } \\
\mathrm{Dt}=\mathrm{N} \mu / \mathrm{P}\end{array}$ & (Horton, 1932) \\
\hline 10 & Drainage texture (Dt) & $\begin{array}{c}\text { Where } \mathrm{N} \mu=\text { total no of } \\
\text { streams of all orders, } \mathrm{P}= \\
\text { perimeter of the watershed }\end{array}$ & (Horton, 1945) \\
\hline 11 & Elongation ratio $(\mathrm{Re})$ & $\begin{array}{c}\mathrm{Re}=2 \sqrt{\mathrm{A}} / л) / \mathrm{Lb}, \text { Where } \\
\mathrm{A}=\text { area of a watershed, } \\
л=3.41, \mathrm{Lb}=\text { length of } \\
\text { watershed }\end{array}$ & (Schumm, 1956) \\
\hline 12 & Circularity ratio (Rc) & $\begin{array}{c}\mathrm{Rc}=4 л \mathrm{~A} / \mathrm{P} 2 \\
\text { Where } \mathrm{A}=\text { area of the } \\
\text { watershed, } л=3.41 \\
\mathrm{P}=\text { perimeter of watershed }\end{array}$ & (Miller, 1953) \\
\hline 13 & Form factor (Ff) & $\begin{array}{c}\mathrm{Rf}=\mathrm{A} / \mathrm{Lb} 2 \\
\text { Where } \mathrm{A}=\text { area of a } \\
\text { watershed, } \mathrm{Lb}=\text { length of } \\
\text { watershed }\end{array}$ & (Horton, 1945) \\
\hline 14 & Basin relief $(\mathrm{R})$ & $\begin{array}{c}\mathrm{R}=\mathrm{H}-\mathrm{h} \text {, where } \mathrm{H} \text { is a } \\
\text { great elevation, and } \mathrm{h} \text { is } \\
\text { Minimum elevation within } \\
\text { the basin }\end{array}$ & (Chorley et al., 1957) \\
\hline 15 & Relief ratio (Rr) & $\begin{array}{l}\mathrm{Rr}=\mathrm{R} / \mathrm{Lb}, \text { Where } \mathrm{R}=\text { basin } \\
\text { relief, } \mathrm{Lb}=\text { length of basin }\end{array}$ & (Schumm, 1956) \\
\hline 16 & Ruggedness number (RN) & $\begin{array}{c}\mathrm{RN}=\mathrm{H}^{*} \mathrm{Dd}, \mathrm{H}=\text { Maximum } \\
\text { watershed relief, } \mathrm{Dd}= \\
\text { density of drainage }\end{array}$ & (Melton, 1957) \\
\hline 17 & $\begin{array}{l}\text { Constant of channel } \\
\text { maintenance }\end{array}$ & $\mathrm{C}=1 / \mathrm{Dd}(\mathrm{km} 2 / \mathrm{km})$ & (Schumm, 1956) \\
\hline 18 & Infiltration number (If) & $\mathrm{If}=\mathrm{Fs} * \mathrm{Dd}$ & $\begin{array}{l}\text { (Jasmin and } \\
\text { Mallikarjuna, 2013; } \\
\text { Agarwal, 1998). }\end{array}$ \\
\hline
\end{tabular}




\subsection{Potential Groundwater Recharge Areas}

A scale from 1- 4 was used to evaluate the areas in which potential groundwater recharge will occur and be potential groundwater areas, where the number 4 is given to the lowest value for the parameter and the number 1 to the largest value, which gives a measure for both the values for the infiltration number, the shape factor, drainage density, drainage texture, elongation rate, ruggedness number, stream frequency, circularity rate, bifurcation rate and relief ratio, for each basin. Thus, the value 4 of the scale indicates the lowest value for each parameter in all basins, and the value 1 indicates the largest value for each parameter in All basins and on this basis, it is possible to measure the parameters and deduce potential areas for groundwater recharge (Jasmin and Mallikarjuna, 2013; Pakhmode et al., 2003; OstadAli-Askari and Shayannejad, 2021 ).

\section{Results and Discussion}

The morphometric analysis was conducted with remote sensing techniques on the DEM using GIS. This study attempted to identify potential groundwater zones using remote sensing and geographic information system techniques in the East Wasit area. To demarcate the groundwater availability of the area. The results showed there are four Basins in the study area. Fig. 4 shows the locations of basins and streams in the study area. The morphometric analysis gives a relationship between the different linear aspects, terrain and the area inside the basin (Deepika et al., 2013). The morphometric analysis was performed for the sub-basins in the study area. Tables 2, 3 and 4 show the basins' morphometric analysis results, where there are four watersheds. According to drainage stream order, the watersheds in the study area first basins and second are of the sixth order, third and fourth basin of fourth-order. Figure 9 shows the streams orders of the four basins for the study area.

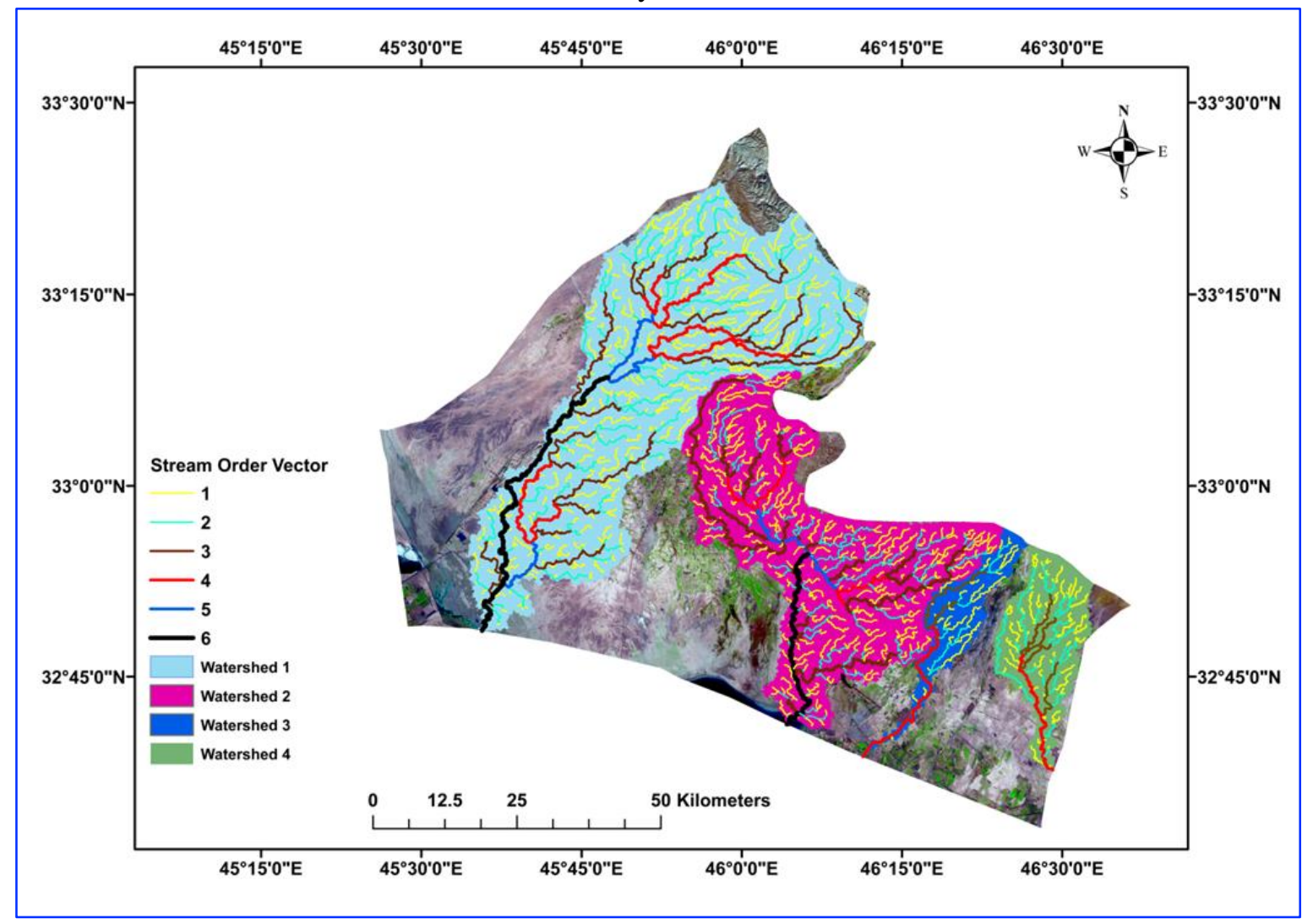

Fig. 4. location basin and streams in the study area (based on the image of the Sentinel-2(2021) satellite, using the ArcGIS program) 


\subsection{Slope and Aspect}

The slope is an essential feature in shape studies, as the slope directly affects the formation of drainage networks and the slope elements. Understanding the distribution of slopes is necessary because it provides data for planning, planning engineering structures and agriculture (Sreedevi et al., 2005). The result showed that the slope values for the study area ranged between 55.465-0. Fig. 5 illustrates the study area's slope map, where the slope is the highest proportion of alteration in value from each cell to its neighbors. Many factors affect the slope's shape, such as the terrain, land cover, geomorphological processes, and soil. The slope map provides information on morphology preservation practices and the planning of engineering structures. Hence, it is necessary to understand the distribution of slopes. Slope analysis is an essential geomorphological feature as it provides essential data for watershed development (Shamkhi et al., 2019). Aspect is the direction that the slope goes toward, and the side of the slope greatly influences the local climate (Magesh and Chandrasekar, 2014). Fig.6 illustrates the aspect map of the study area. The aspect shows the direction the mountain slope faces (Agarwal, 1998).

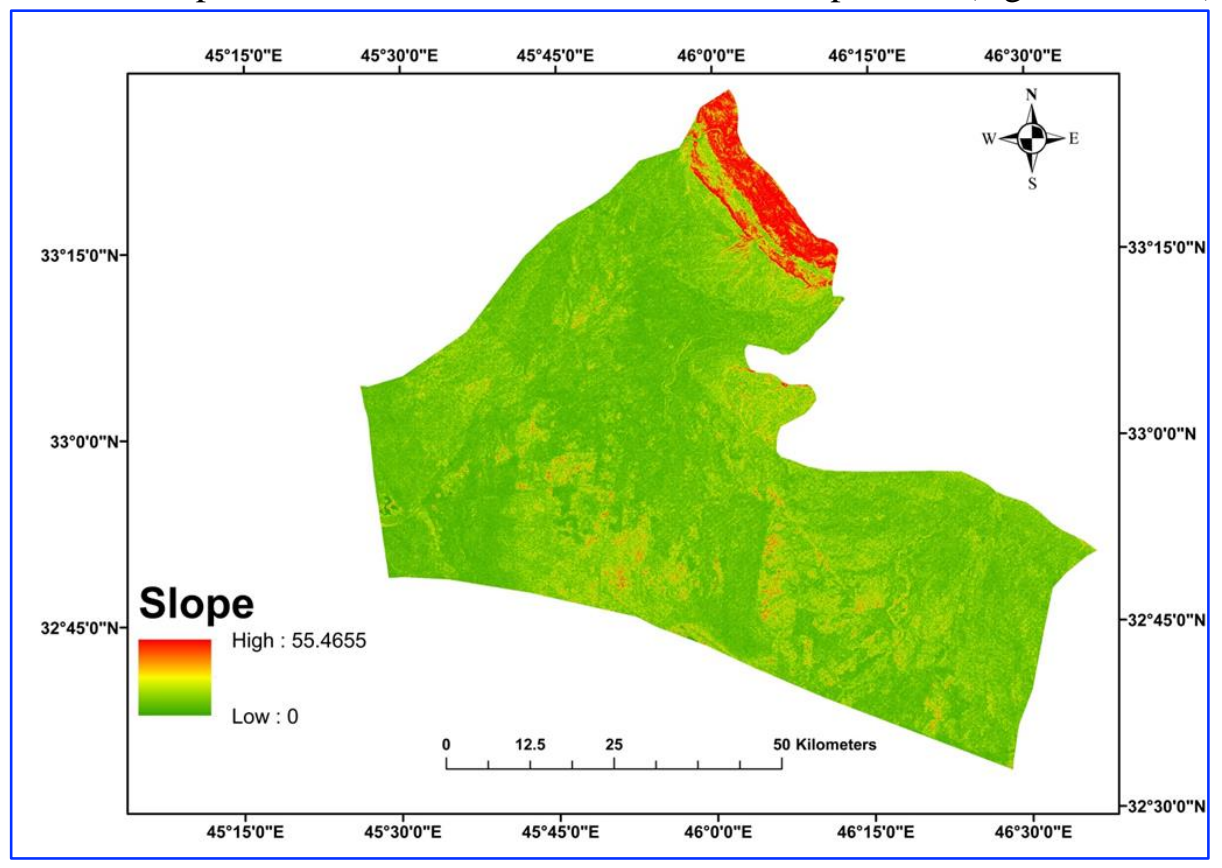

Fig. 5. Slope map of the study area (based on the digital elevation model DEM produced by SRTM and using ArcGIS s program (Slope tool)).

\subsection{Stream Order (u) and Stream Number $(\mathrm{Nu})$}

The morphometric analysis of the basin in our present study follows the strahler1964 method for arranging the flows according to this method. The first and second basins were of the sixth category. Moreover, the third and four basins were Class 4, according to the strahler1964 classification system. A flux without tributaries is designated as a Class I stream. When two currents of the first degree meet, we get a second-degree flow; when two currents of different degrees meet, we get a flux equal to the higher current's degree, and so on. The number of flows decreases as the order of these flows increases. Fig.9 illustrates the Stream order and basin. The results showed that the streams number in the first basin 806 , in the second basin 390, in the third basin 49, and the fourth basin 99. Fig.7 shows the percentage of stream segment for four Watersheds in the study area. 


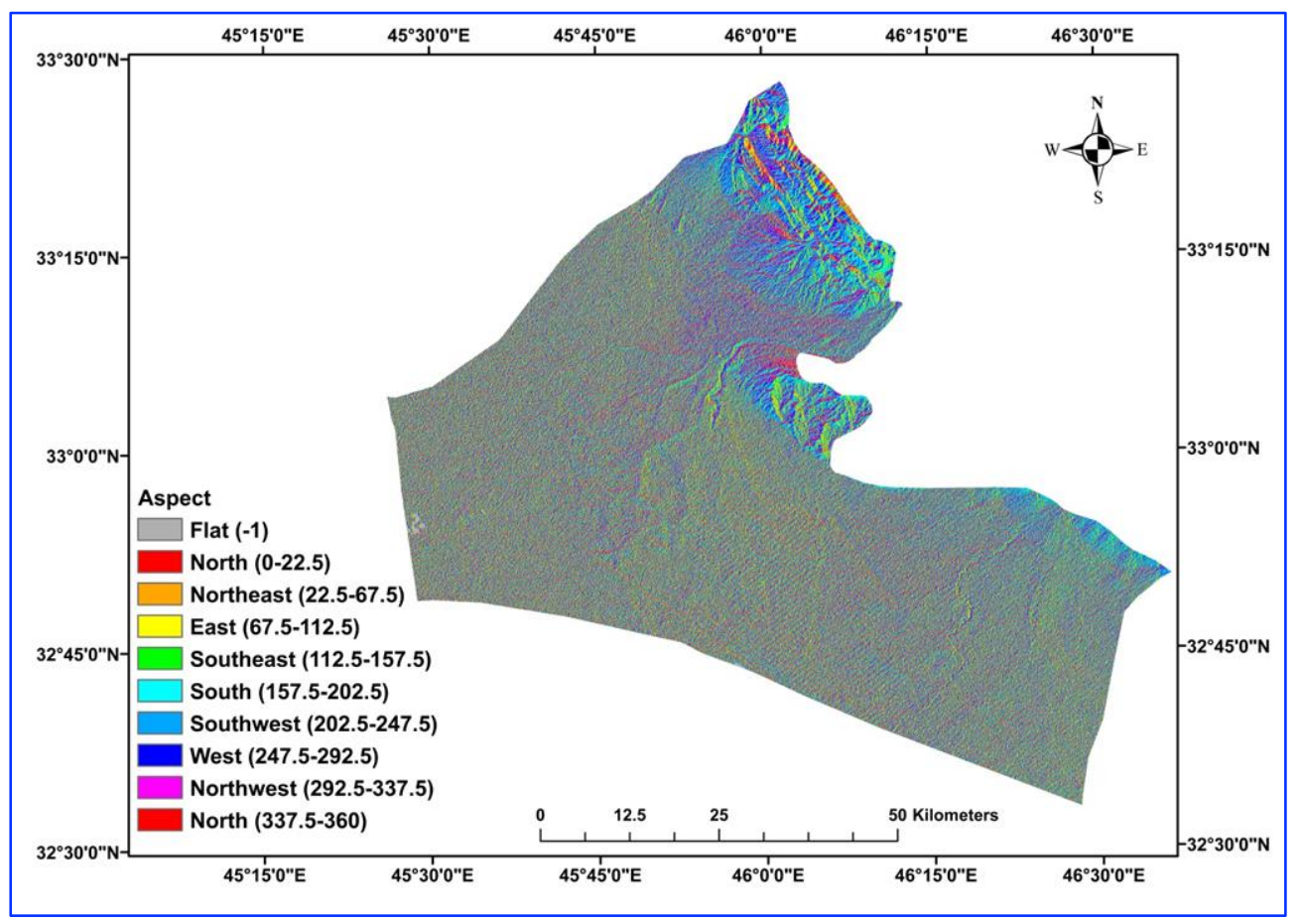

Fig.6. Aspect map of the study area (based on the digital elevation model DEM produced by SRTM and using ArcGIS s program (Aspect tool)

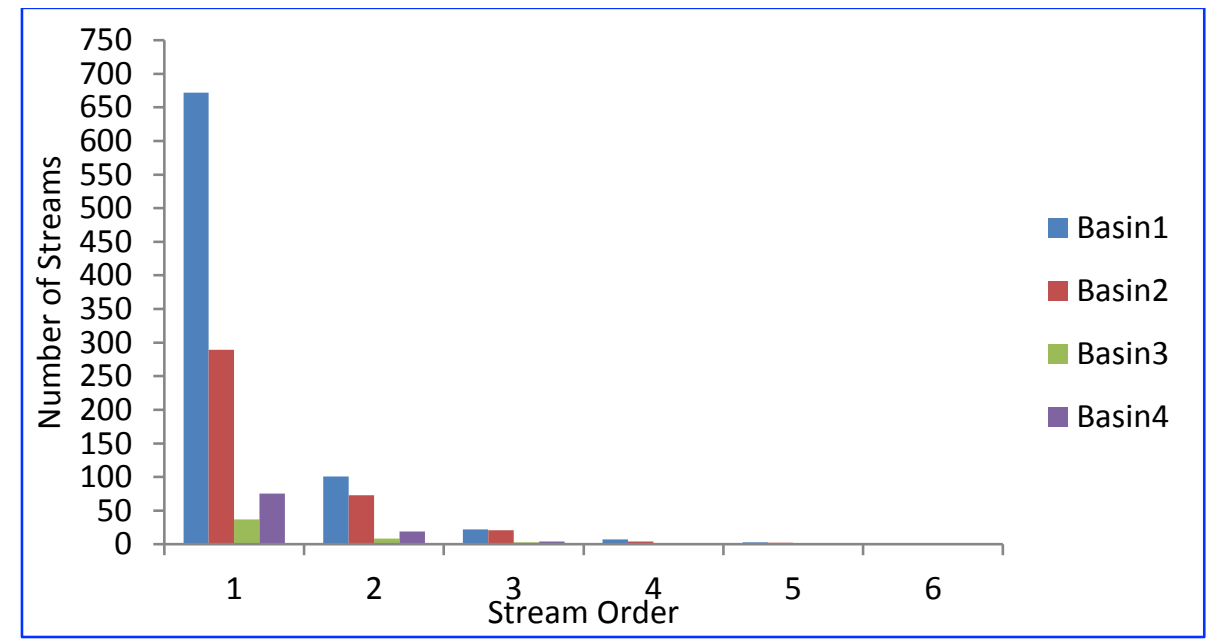

Fig.7. The percentage of stream segment for four watersheds in the study area

\subsection{Stream Length $(\mathrm{Lu})$}

Total stream lengths of each stream order basin were calculated using the Engineering Calculation Tool, one of the GIS software tools. The first segment is the rate length of the current in the first order (Horton, 1945). The results showed the total length of streams in the first basin $1461.427 \mathrm{~km}$, the second basin $1081.15741 \mathrm{~km}$, the third basin 164.21782 and the fourth basin $298.46 \mathrm{~km}$. It is an essential characteristic of water basins, as it is concerned with surface runoff characteristics. Streams of smaller length are located within slopes of a delicate texture, while long currents are within flat areas. The length of the stream indicates the contributing area from the basin to set the order. The stream's length is a scale of the base rocks' hydrological properties and the extent of drainage (Magesh and Chandrasekar, 2014). When the rock formations are less permeable, we obtain many streams. When the formations are porous, there are few relatively long streams in the watersheds (Sethupathi et al., 2011). 


\subsection{Mean Stream Length (Lsm)}

The sum of the length of the stream order of each basin to the number of the longest. Fig. 8 shows the mean stream length for four watersheds in the studying area

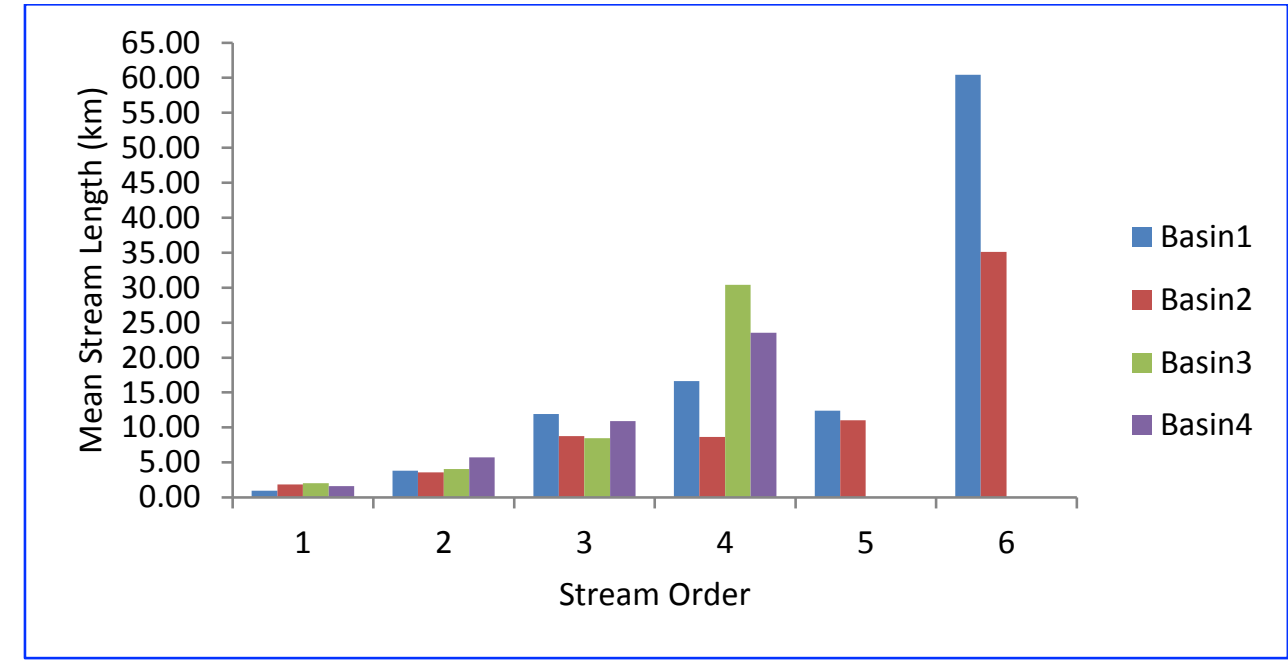

Fig. 8. Mean stream length for four watersheds in studying area

\subsection{Stream Length Ratio (RL.)}

The ratio of the average current length of a given arrangement to the average length of the preceding arrangement's path (Horton, 1945).

\subsection{Bifurcation Ratio (Rb)}

The number of flows for a given order to the number of flows for the next higher order (Schumm, 1956) $\mathrm{Rb}$ 's value is high for a longitudinal basin, and $\mathrm{Rb}$ is low for a round basin. Where the value of the bifurcation ranged for the first (2.334-6.653), second (1-5.25), third (2.667-4.625), and fourth basin (3.947-4.75) Mean bifurcation ratio ( $\mathrm{Rbm}$ ) for all basins value (3.135-4.233). Value (Rbm)indicates that the basins are subject to rapid seasonal floods (Makhamreh et al., 2020) as flash floods form suddenly in semi-arid and arid areas and that these floods are considered a dangerous geomorphological hazard to human constructions because watercourses are fast with high hierarchical classification erosion rates lead to high rates of soil erosion in the water basin, which causes significant losses to farmers (Rai et al., 2017).

\subsection{Frequency of Stream (Fs)}

It is the sum of the stream orders per unit area (Horton, 1932). The stream's frequency refers to the falling water's ability to cause surface runoff formation in the structure of the water basin. This variable also indicates the proportion of water that replenishes the groundwater. Stream frequency range values (0.543-0.332) note that the current frequency value is low, and this indicates that basins in semi-arid and arid areas receive small amounts of rain, which is the main factor affecting the frequency of the stream (Makhamreh et al., 2020). The Stream Frequency indicates that the drainage network is low and more minor relief (Verma et al.,2020).

\subsection{Drainage Texture}

It is the sum of the stream order of the basin to the perimeter of the basin. Horton's analysis; infiltration capacity is the primary variable that affects the drainage texture and the ratio of that texture, including density and current frequency (Verma et al., 2020). Smith (1950) divided the drainage density 
into five parts. very coarse (<2), Coarse (2-4), moderate (4-6), fine (6-8) and very fine (>8). It depends on the geological composition, soil types, vegetation cover, topography, infiltration rate, and precipitation in the basin (Horton, 1945). According to this classification, all basins have a very coarse drainage texture of less than 2 except for the first watershed with 2.62 coarse drainage texture.

\subsection{Drainage Density (Dd)}

It is the rate of the sum of the stream's length of the basin to the basin's area. When the drainage density is high, the soil is impermeable, the vegetation cover is not dense, and when the drainage density is low, the land is with dense vegetation cover and permeable soil. Drainage density is affected by factors that regulate the appropriate length of a watershed. Drainage density is linked to landscape analysis features such as valley density, canal head source area, climate, vegetation, cover topography (Moglen, 1998), and soil and rock properties (Kelson et al., 1989). The density of drainage shows the physical characteristics of the primary rocks in the watersheds. The watersheds in the studied area all show a low drainage density that ranged between $(0.986-1.14) \mathrm{km} / \mathrm{km} 2$ as the low drainage density is an indication that the land has high permeability, low topography, dense vegetation cover and strong rocks in contrast to areas with high drainage density (Nag, 1998).

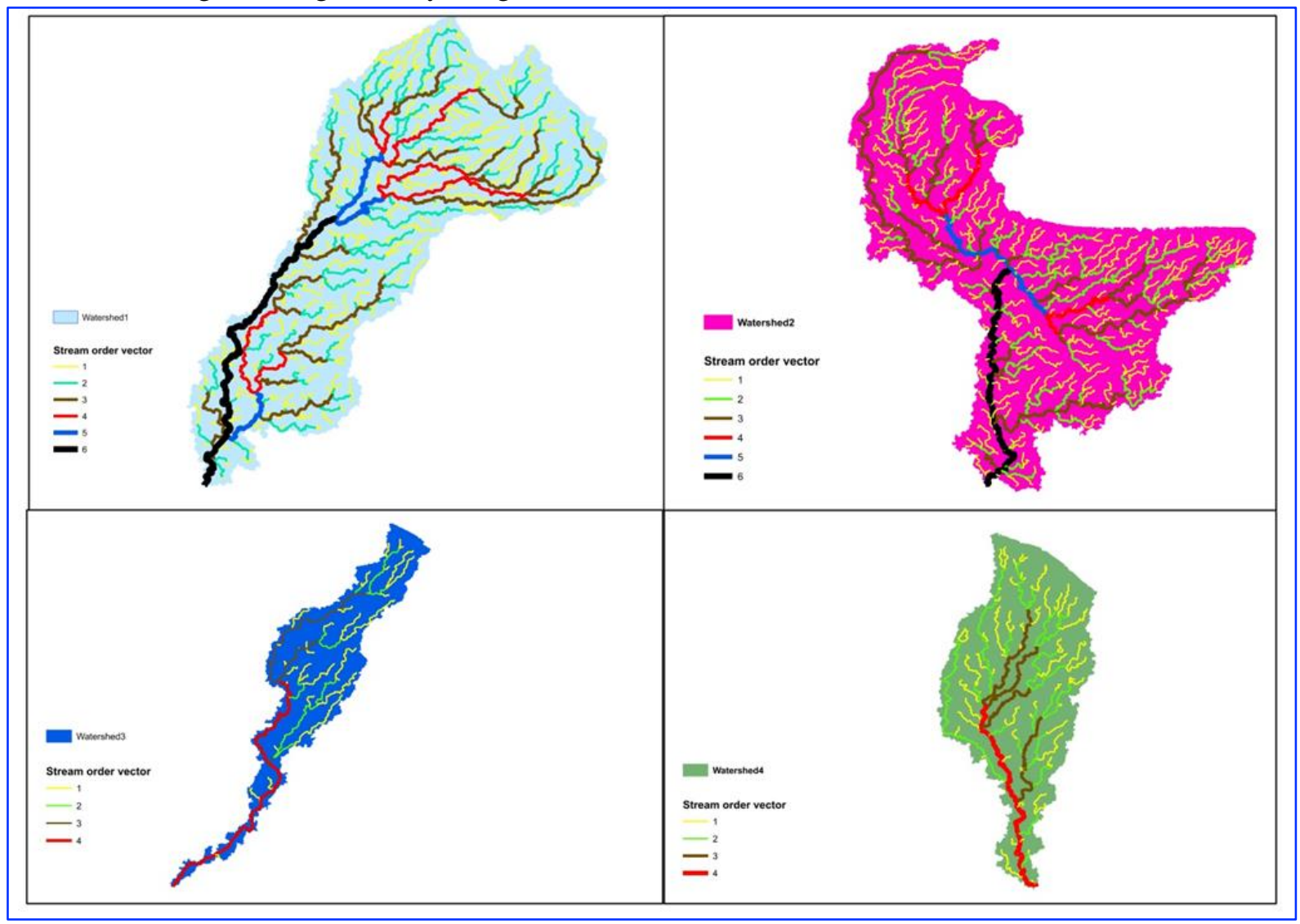

Fig.9. Stream order of four basins for the study area (based on the digital elevation model DEM produced by SRTM and using ArcGIS s program (hydrological analysis tools)

\subsection{Elongation Ratio (Re)}

The proportion between the area of a circle equals the basin's area and the most extensive length. This ratio ranges typically from 0.6 to 1.0 over a wide range of the climatic and geological model. Values close to 1.0 are typical for low terrain, while values 0.51 to 0.94 are associated with substantial relief and a steep slope. The ratio is a vital sign for analyzing drainage basins into various shapes, so while 
circular (above 0.9), oval (0.8-0.9), least elongated (0.7-0.8) and long (less than 0.7) Pradhan et al., 2020). All basins in the study area were longitudinal, with elongation ratio ranging from o.348-0.624. Longitudinal Watershed led to soil erosion due to high peak hydrographs.

\subsection{Form Factor (FF)}

Scientist Horton defines the shape parameter as the ratio between the basin's area to the square of its most significant length. The values of the form factor of the basins in the study area ranged from 0.095-0.316 which indicates that the water basins in the study area are more elongated and the branch currents flow into the mainstream with more significant periods and greater distance, which leads to the recharge of groundwater as well as areas of saturation also form. As a result, water quickly carries sediments, and floods are formed.

\subsection{Circularity Ratio (Rc)}

The ratio between the basin area to the area of a circle having the same circumference as the basin's perimeter (Miller, 1953). The basins' circularity ratio value range (0.105-0.238) is low, which indicates that all basins are of a longitudinal shape and cause flooding problems and soil erosion.

\subsection{Basin Relief $(\mathbf{R})$}

The is a difference between the highest and lowest point in the basin. Basin topography was extracted from the DEM. The basin relief value (951-112) $\mathrm{m}$ plays an essential role in forming ground shapes and has a vital role in the flow of surface and groundwater and the development of drainage and affects the permeability and erosion of the terrain (Magesh and Chandrasekar, 2014).

\subsection{Relief Ratio (Rr)}

The ratio between the basin's total relief and the longer dimensions of the basin parallel to the main drainage line (Schumm,1956). The relief ratio value for all basins ranged from 0.0021-0.0125. These values show the corrosion processes' intensity working on the basin's slopes (Magesh and Chandrasekar, 2014).

\subsection{Ruggedness Number $(R N)$}

It indicates the complexity of the topographic structure, and it is a product of the drainage density and basin relief. This variable gives the relationship between drainage intensity and total calcification in the watershed. A value greater than 1 represents a high level of roughness, while a value of less than 1 represents a low value. The value $\mathrm{RN}$ for all basins in the study area $(0.937,0.123,0.105$ and 0.124$)$, the result shows that Low values indicate a moderato hardens for all basin.

\subsection{Length Overland Flow (Lg)}

It is the distance that runoff travels before reaching specific stream channels. The average length of the overland flow $=1 / 2 * \operatorname{Dd}$ (Horton, 1945). Overland flow length also indicates the drainage density in the basin. The overland flow value for basins $(0.19,0.347,0.592$ and 1.358) respectively. As shown in Table 2. The larger value indicates the flow Overland to longer flow paths and more moderate slopes. The high overland flow value gives low comfort, while the low value gives great relief. The low value means that the basins are located within a high and low area and that surface rainwater runs a short distance and reaches the stream. Also, rainwater will enter the stream very quickly (Pradhan et al., 2020). 
Table 2. Basins characterizes

\begin{tabular}{lcccc}
\hline Basin & $\mathbf{1}$ & $\mathbf{2}$ & $\mathbf{3}$ & 4 \\
\hline Area Km2 & 1482.017 & 1001.999 & 147.594 & 261.316 \\
Basin Length (Lb) km & 75.857 & 56.3 & 39.4 & 32 \\
Perimeter (p) km & 307.314 & 270.691 & 132.821 & 117.264 \\
& & & & 99 \\
Number of Streams (NU) & 806 & 390 & 164.21782 & 298.46 \\
Length of stream, km & 1461.427 & 1081.15741 & & \\
& & & 1.358 & 0.592 \\
Length of overland flow & 0.19 & 0.347 & 1.112 & 1.142 \\
(Lg)km/km2. & 0.986 & 1.07 & 0.332 & 0.378 \\
Drainage density (Dd) & 0.543 & 0.389 & 0.368 & 0.844 \\
Stream frequency (Fs) & 2.622 & 1.440 & 0.348 & 0.570 \\
Drainage texture (Dt) & 0.572 & 0.634 & 0.105 & 0.238 \\
Elongation ratio (Re) & 0.197 & 0.171 & 0.095 & 0.255 \\
Circularity ratio (Rc) & 0.257 & 0.316 & 112 & 92 \\
Form factor (Ff) & 951 & 120 & 0.002842 & 0.002875 \\
Basin relief (R) m & 0.01251 & 0.0021 & 0.124 & 0.105 \\
Relief ratio (Rr) & & 0.128 & 0.9 & 0.875 \\
& 1.014 & 0.934 & 0.369 & 0.431 \\
\hline Ruggedness number (RN) & 0.535 & 0.416 & & \\
Constant of channel & & &
\end{tabular}

\subsection{Constant of Channel Maintenance}

It is opposite to the drainage density, which is required to maintain one kilometer of the flow channel. A high value indicates a high permeability to the basin rocks, and a low value indicates low permeability (Schumm, 1956). The large value(1/Dd) In the first basin, 1.014 and less the value (1/Dd) 0.875 for the fourth basin indict the first basin, it more permeability.

\subsection{Infiltration Number (If)}

The result of multiplying the drainage density by the stream frequency (Jasmin and Mallikarjuna, 2013). the infiltration number value range for all basins (0.369-0.535). The lower value of the filter number in the basins indicates higher percolation rates leading to groundwater recharge. According to the result of the morphometric analysis, the third basin obtained the lowest value of the infiltration number and the lowest value of the shape factor and the drainage texture and the stream frequency and the elongation rate and the circularity rate, as well as the value of the bifurcation ratio and ruggedness number, are low. Simultaneously, the relief ratio's value was moderate, and these results give the basin the highest filtration rate, coarse texture and an elongated longitudinal basin. Stream Suitable for recharge groundwater, and an appropriate branching ratio, indicating that the basin is receiving for the groundwater recharge, as well as the results of the second basin, were close to the results of the third basin, followed by the fourth basin, then the first that obtained a high value for most of the parameters that are inversely proportional to the values of the proportion Filtration and permeability Table No. 5 shows the results of the scale 1-4 that was used to identify potential areas for groundwater recharge from the parameters of the morphometric analysis, as it shows the order of parameters for each basin. 
Table 3. Stream characteristics for the first and second watersheds

\begin{tabular}{|c|c|c|c|c|c|c|}
\hline \multicolumn{7}{|c|}{ Watershed1 } \\
\hline $\begin{array}{l}\text { Stream } \\
\text { order }\end{array}$ & $\begin{array}{c}\text { No.of } \\
\text { Streams }\end{array}$ & $\begin{array}{l}\text { Stream Length, } \\
\text { Lu (km) }\end{array}$ & $\begin{array}{c}\text { Mean Stream } \\
\text { Length, Lsm }(\mathrm{km})\end{array}$ & $\begin{array}{c}\text { Stream } \\
\text { Ratio, } \mathrm{R}\end{array}$ & $\begin{array}{l}\text { Bifurcation } \\
\text { Ratio, } \mathrm{Rb}\end{array}$ & $\begin{array}{l}\text { Mean Bifurcation } \\
\text { Ratio, Rbm }\end{array}$ \\
\hline 1 & 672 & 661.4266 & 0.984 & & & \multirow{6}{*}{3.944} \\
\hline 2 & 101 & 384.1501 & 3.8 & 0.58 & 6.653 & \\
\hline 3 & 22 & 262.1949 & 11.91 & 0.682 & 4.59 & \\
\hline 4 & 7 & 116.3983 & 16.63 & 0.443 & 3.143 & \\
\hline 5 & 3 & 37.25826 & 12.42 & 0.320 & 2.334 & \\
\hline 6 & 1 & 60.41384 & 60.41 & 1.621 & 3 & \\
\hline $\begin{array}{l}\text { Stream } \\
\text { order }\end{array}$ & $\begin{array}{l}\text { No. of } \\
\text { Streams }\end{array}$ & $\begin{array}{l}\text { Stream Length, } \\
\text { Lu }(\mathrm{km})\end{array}$ & $\begin{array}{l}\text { Watershed2 } \\
\text { Mean Stream } \\
\text { length Lsm }(\mathrm{km})\end{array}$ & $\begin{array}{c}\text { Stream } \\
\text { Ratio, R }\end{array}$ & $\begin{array}{l}\text { Bifurcation } \\
\text { Ratio, } \mathrm{Rb}\end{array}$ & \multirow[t]{3}{*}{$\begin{array}{l}\text { Mean Bifurcation } \\
\text { Ratio, Rbm }\end{array}$} \\
\hline 1 & 289 & 540.9236 & 1.8717 & & & \\
\hline 2 & 73 & 263.8268 & 3.614 & 0.4877 & 3.958 & \\
\hline 3 & 21 & 184.5889 & 8.7899 & 0.6996 & 3.476 & \multirow[t]{4}{*}{3.135} \\
\hline 4 & 4 & 34.667 & 8.666 & 0.1878 & 5.25 & \\
\hline 5 & 2 & 22.0576 & 11.0288 & 0.6362 & 2 & \\
\hline 6 & 1 & 35.093 & 35.093 & 1.5909 & 1 & \\
\hline
\end{tabular}

Table 4. Stream characteristics for the third and Fourth Watersheds

\begin{tabular}{|c|c|c|c|c|c|c|c|}
\hline \multicolumn{8}{|c|}{ Watershed3 } \\
\hline $\begin{array}{l}\text { Stream } \\
\text { order }\end{array}$ & $\begin{array}{l}\text { No. of } \\
\text { Streams }\end{array}$ & $\begin{array}{l}\text { Stream Length, Lu } \\
(\mathrm{km})\end{array}$ & $\begin{array}{l}\text { Mean Stream } \\
\text { length Lsm }(\mathrm{km})\end{array}$ & $\begin{array}{l}\text { Stream } \\
\text { Ratio, R }\end{array}$ & $\begin{array}{l}\text { Bifurcation } \\
\text { Ratio, } \mathrm{Rb}\end{array}$ & $\begin{array}{l}\text { Mean } \\
\text { Ratio, Rbm }\end{array}$ & Bifurcation \\
\hline 1 & 37 & 75.88239 & 2.05 & & & & \\
\hline 2 & 8 & 32.44982 & 4.056 & 0.427 & 4.625 & & \\
\hline 3 & 3 & 25.46649 & 8.488 & 0.784 & 2.667 & 3.45 & \\
\hline 4 & 1 & 30.41912 & 30.41912 & 1.194 & 3 & & \\
\hline \multicolumn{8}{|c|}{ Watershed4 } \\
\hline $\begin{array}{l}\text { Stream } \\
\text { order }\end{array}$ & $\begin{array}{l}\text { No.of } \\
\text { Streams }\end{array}$ & $\begin{array}{l}\text { Stream Length, Lu } \\
(\mathrm{km})\end{array}$ & $\begin{array}{l}\text { Mean Stream } \\
\text { length Lsm }(\mathrm{km})\end{array}$ & $\begin{array}{l}\text { Stream } \\
\text { Ratio, } \mathrm{R}\end{array}$ & $\begin{array}{l}\text { Bifurcation } \\
\text { Ratio, } \mathrm{Rb}\end{array}$ & $\begin{array}{l}\text { Mean } \\
\text { Ratio, Rbm }\end{array}$ & Bifurcation \\
\hline 1 & 75 & 122.3716 & 1.631 & & & \multirow{4}{*}{4.2334} & \\
\hline 2 & 19 & 108.7345 & 5.723 & 0.888 & 3.947 & & \\
\hline 3 & 4 & 43.78229 & 10.945 & 0.402 & 4.75 & & \\
\hline 4 & 1 & 23.57161 & 23.571 & 0.538 & 4 & & \\
\hline
\end{tabular}

The results show that groundwater recharge occurs in all basins and that the third basin is more likely to obtain groundwater recharge than from the second basin. In contrast, the probability of groundwater recharge in the second basin was more than in the fourth basin, and the likelihood of groundwater recharge occurs in the fourth basin larger than in the first. The result also applies to potential groundwater areas where they are the same as potential groundwater recharge locations.

Table 5. The scale used for morphometric parameters

\begin{tabular}{lllllllllll}
\hline Basin no. & Rb & Dd & Fs & If & Dt & Rf & Rh & Rc & Re & RN \\
\hline 1 & 2 & 4 & 1 & 1 & 1 & 2 & 1 & 2 & 2 & 1 \\
2 & 4 & 3 & 2 & 3 & 2 & 1 & 4 & 3 & 1 & 2 \\
3 & 3 & 2 & 4 & 4 & 4 & 4 & 2 & 4 & 4 & 3 \\
4 & 1 & 1 & 3 & 2 & 3 & 3 & 3 & 1 & 3 & 4 \\
\hline
\end{tabular}




\section{Conclusions}

The current study was prepared for the purpose of conducting a morphometric analysis of the eastern region of the Wasit and evaluating the potential areas for groundwater recharge. The morphometric analysis showed the presence of four basins in the study area. The results of the analysis were verified by matching the results with what exists in reality. The area of the first basin was 1482.017, as it is the largest basin from the area, with a percent of $51.228 \%$ of the total area of all basins. The percentage of the number of first-degree flows reached $83.37 \%$ in the first basin, $74.14 \%$ percent in the second basin, $75.51 \%$ in the third basin, and $75.75 \%$ in the fourth basin from all streams in each basin. Drainage analysis values constitute a useful tool in selecting potential sites for groundwater recharge because they provide comparative indicators of the permeability capacity of the rocky surfaces of each basin. If these values are combined with the observed hydrogeological characteristics of the drainage basin, the siting strategy and water collection measures become effective. The morphometric analysis was conducted to be an effective method in evaluating the watersheds for water conservation and management and providing good information about the shape of the basins and their topography. Furthermore, the evaluation using GIS helps understand the different hydrogeological characteristics of the basin where it is possible to understand the land shapes and patterns of drainage for planning and sustainable management. The morphometric analysis results showed that the Wasit governorate's eastern region has different terrains between high border areas and flat bare areas and between the morphometric analysis. Most parts of the eastern and southern region are exposed to severe seasonal floods, as well as that the drainage streams in the region are not suitable where floods occur that lead to damage Soil and agricultural lands as well as between analysis of drainage texture, drainage density and infiltration number the ground is rough to the touch and high permeability, which allows the recharge of groundwater.

\section{Acknowledgements}

The authors extend their sincere thanks and gratitude to Wasit University-College of Engineering, and the General Authority for Groundwater, Wasit Branch. The authors are very grateful to the Editor in Chief Prof. Dr. Salih M. Awadh, the Secretary of Journal Mr. Samir R. Hijab. and the Technical Editors for their great efforts and valuable comments.

\section{References}

Agarwal, C. S., 1998. Study of drainage pattern through aerial data in Naugarh area of Varanasi district, UP. Journal of the Indian Society of Remote Sensing, 26(4).169-175.

Al-Ansari, N., 2013. Management of water resources in Iraq: perspectives and prognoses. Engineering, 5(6), 667684.

Al-Hamdani, J. A., Merkel, H.B.J., Awadh, S.M. and Ibrahim, O.S., 2016b. Natural attenuation modelling of heavy-metal in groundwater of Kirkuk City, Iraq. Iraqi Journal of Science, 57(3B).

Al-Hamdani, J.A.J., Awadh, S.M. and Ibrahim, O.S., 2016a. Geochemical partitioning of heavy metals in the urban soil, Kirkuk, Iraq. The Iraqi Geological Journal, 1-24.

Awadh, S.M. and Ahmad, L.M., 2012. Climatic prediction of the terrestrial and coastal areas of Iraq. Arabian Journal of Geosciences, 5(3),465-469.

Chorley, R.J., Malm, D.E., and Pogorzelski, H. A., 1957. A new standard for estimating drainage basin shape. American Journal of Science, 255(2), 138-141.

Deepika, B., Avinash, K. and Jayappa, K.S., 2013. Integration of hydrological factors and demarcation of groundwater prospect zones: insights from remote sensing and GIS techniques. Environmental Earth Sciences, 70(3),1319-1338.

Dwivedi, S. C., 2011. Morphometric analysis of for sub-watershed in bah area of Agra district using remote sensing and GIS techniques. In 12th Esri India User Conf Noida, India, 1, 11. 
Hilo, A.N. and Saeed, M.S.F.H., 2019. Hydrologic study for the watershed of Shweicha Wetland using remote sensing data and SWAT hydrologic model. International Journal of Civil Engineering and Technology, 10(1), 2747-2754.

Horton, R.E., 1932. Drainage-basin characteristics. Eos, transactions american geophysical union, 13(1), 350-361.

Horton, R.E., 1945. Erosional development of streams and their drainage basins; hydro physical approach to quantitative morphology. Geological society of America bulletin, 56(3), 275-370.

Jasmin, I. and Mallikarjuna, P., 2013. Morphometric analysis of Araniar river basin using remote sensing and geographical information system in the assessment of groundwater potential. Arabian Journal of Geosciences, 6(10), 3683-3692.

Kacem, L., Igmoullan, B., Mokhtari, S., Amar, H. and Agoussine, M.B., 2014. Morphometric characterization of upstream mountainous watershed using geographic information system GIS: high valley of Tifnoute High Moroccan Atlas. J Biodivers Environ Sci, 5(6), 62-66.

Kelson, K.I. and Wells, S.G., 1989. Geologic influences on fluvial hydrology and bedload transport in small mountainous watersheds, northern New Mexico, USA. Earth surface processes and landforms, 14(8), 671690.

Kulkarni, H., 1998. Watershed development and management-a movement seeking inputs in earth sciences. Journal of the Geological Society of India, 52(2), 239-241.

Magesh, N.S. and Chandrasekar, N., 2014. GIS model-based morphometric evaluation of Tamiraparani subbasin, Tirunelveli district, Tamil Nadu, India. Arabian Journal of Geosciences, 7(1), 131-141.

Makhamreh, Z., Al-Hawary, M. and Odeh, S., 2020. Assessment of morphometric characteristics of Wadi AlShumar catchment in Jordan. Open Journal of Geology, 10(02), 155.

Mallick, J., Khan, R.A., Ahmed, M., Alqadhi, S.D., Alsubih, M., Falqi, I. and Hasan, M.A., 2019. Modeling groundwater potential zone in a semi-arid region of Aseer using fuzzy-AHP and geoinformation techniques. Water, 11(12), 2656.

Manhi, H.K. and Al-Kubaisi, Q.Y.S., 2021. Estimation annual runoff of Galal Badra transboundary watershed using Arc Swat Model, Wasit, East of Iraq. Iraqi Geological Journal, 69-81.

Melton, M.A., 1957. An analysis of the relations among elements of climate, surface properties, and geomorphology. Columbia Univ New York.

Miller, v.c., 1953. A Quantitative Geomorphic Study of Drainage Basin Characteristics in the Clinch Mountain Area Virginia And Tennessee. Columbia univ new york.

Moglen, G.E., Eltahir, E.A. and Bras, R.L., 1998. On the sensitivity of drainage density to climate change. Water Resources Research, 34(4), 855-862.

Nag, S. K., 1998. Morphometric analysis using remote sensing techniques in the Chaka sub-basin, Purulia district, West Bengal. Journal of the Indian Society of Remote Sensing, 26(1), 69-76.

Nasir, M.J., Iqbal, J. and Ahmad, W., 2020. Flash flood risk modeling of swat river sub-watershed: a comparative analysis of morphometric ranking approach and El-Shamy approach. Arabian Journal of Geosciences, 13(20), 1-19.

Ostad-Ali-Askari, K. and Shayannejad, M., 2021. Quantity and quality modelling of groundwater to manage water resources in Isfahan-Borkhar Aquifer. Environment, Development and Sustainability, 1-17.

Ostad-Ali-Askari, K., Ghorbanizadeh Kharazi, H., Shayannejad, M. and Zareian, M.J., 2019. Effect of management strategies on reducing negative impacts of climate change on water resources of the IsfahanBorkhar aquifer using MODFLOW. River Research and Applications, 35(6), 611-631.

Ostad-Ali-Askari, K., Ghorbanizadeh Kharazi, H., Shayannejad, M., \& Zareian, M. J., 2020. Effect of climate change on precipitation patterns in an arid region using GCM Models: Case Study of Isfahan-Borkhar Plain. Natural Hazards Review, 21(2), 04020006.

Pakhmode, V., Kulkarni, H. and Deolankar, S.B., 2003. Hydrological drainage analysis in watershed-programme planning: a case from the Deccan basalt, India. Hydrogeology Journal, 11(5), 595-604.

Pradhan, A., Chandrakar, T., Kerketta, A., Nag, S.K., and Mukherjee, S.C., 2020. Analysis of GIS based morphometric parameters and hydrological changes in Indrawati River Sub-Basin of Godawari Basin, Chhattisgarh, India. Current Journal of Applied Science and Technology, 72-81.

Rai, P.K., Mohan, K., Mishra, S., Ahmad, A. and Mishra, V.N., 2017. A GIS-based approach in drainage morphometric analysis of Kanhar River Basin, India. Applied Water Science, 7(1), 217-232. 
Schumm, S.A., 1956. Evolution of drainage systems and slopes in badlands at Perth Amboy, New Jersey. Geological Society of America Bulletin, 67(5), 597-646.

Sethupathi, A.S., Narasimhan, C.L., Vasanthamohan, V. and Mohan, S.P., 2011. Prioritisation of miniwatersheds based on Morphometric Analysis using Remote Sensing and GIS techniques in a draught prone BargurMathur subwatersheds, Ponnaiyar River basin, India. International Journal of Geomatics and Geosciences, 2(2), 403-414.

Shamkhi, M.S., Abdullah, T.J. and Mohson, A.J., 2019b. Determination of watershed characteristics using GIS Technique (AL-Adhaim Watershed in Iraq). In AWAM International Conference on Civil Engineering, 277-289. Springer, Cham.

Shamkhi, M.S., Azeez, J.M.R. and Abdul-Sahib, A.A., 2020. Morphologic and engineering characteristics of watersheds; A case study: east Wasit Watersheds that Feed the Al-Shewicha Trough-Iraq. In IOP Conference Series: Materials Science and Engineering (Vol. 870, No. 1, p. 012115). IOP Publishing.

Shamkhi, M.S., Mohson, A.J. and Abdullah, T.J., 2019a. Morphometric analysis of Galal Bedrah River Basin using STRM (DEM) data and GIS techniques. In AWAM International Conference on Civil Engineering, 265-276. Springer, Cham.

Singh, S. and Singh, R.D., 2020, May. Geo-spatial topology based morphometric analysis for soil and water conservation in Dholbaha watershed of Kandi region. In Journal of Physics: Conference Series, 1531, 012087, IOP Publishing.

Smith, K.G., 1950. Standards for grading texture of erosional topography. American journal of Science, 248(9), 655-668.

Sreedevi, P.D., Subrahmanyam, K. and Ahmed, S., 2005. The significance of morphometric analysis for obtaining groundwater potential zones in a structurally controlled terrain. Environmental Geology, 47(3), 412-420.

Strahler, A.N., 1964. Part II. Quantitative geomorphology of drainage basins and channel networks. Handbook of Applied Hydrology: McGraw-Hill, New York, 439 pp.

Verma, R., Kumar, S., Kumar, O.P., Sharma, G. and Bhadauria, P.K.S., 2020. Morphometric analysis of Ken River Basin through remote sensing and GIS techniques. Current Journal of Applied Science and Technology, 122-129. 